\author{
АЛЕКСАНДАР Д. ЋУКОВИЋ*
}

Дневне новине „Дан”, Подгорица

\title{
ПЕРЦЕПЦИЈА КЊИЖЕВНИХ И КУЛТУРНИХ СТРЕМЉЕЊА У ДНЕВНИЧКИМ И ЕСЕЈИСТИЧКИМ ДЈЕЛИМА ДОБРИЦЕ ЋОСИЋА
}

\begin{abstract}
Овај рад се бави перцепцијом књижевних и културних стремљења у дневничким и есејистичким дјелима Добрице Ћосића, прије свих у дјелима као што су „У туђем веку”, „Моћ и стрепње”, „Пишчеви записи” и „Српско питање у XX веку". Такође, рад покушава представити Ћосићево схватање релација као што су књижевност-политика, писац-власт, тенденције у култури, језику, литератури, али и схватања о будућности књиге и сопственог књижевног дјела. Рад се најопштије бави анализом схватања културе и књижевности у дневничким забиљешкама Добрице Ћосића.
\end{abstract} жевност.

Кључне ријечи: Добрица Ћосић, дневници, есеји, записи, култура, књи-

Тема „Перцепција књижевних и културних стремљења у дневничким и есејистичким дјелима Добрице Ћосића" представља покушај сагледавања идеја које је Ћосић заступао када су у питању књижевност и култура уопште, али и анализа друштвених токова који су утицали на њихово формирање. Ћосићев поглед на значајне аспекте фрагмената културе и књижевности, како националног тако и ширег корпуса, поред сагледавања проблема широке тематике, јасније и ближе је изнесен у његовим дневничким, мемоарско-хроничарским и есејистичким дјелима, што нам омогућава да лакше пратимо њихову генезу и компаративно укажемо на њихову постојаност, потврду и домете. Таква ауторова оставштина омогућава нам да његове идеје посматрамо у знатно ширим оквирима, као и то да их пажљивије сагледамо у односу на политички контекст, чији су оне, најшире и најдубље посматрано, нераскидиви дио. Основни фокус овог рада стављен је на дјела Добрице Ћосића: „У туђем веку" (један и два), „Моћ и стрепње”, „Пишчеви записи”, „Српско питање у XX веку", али и на друге изворе који помажу у расвјетљавању и

\footnotetext{
*cukovicaleksandar@yahoo.com
} 
приближавању поменуте тематике, као што су интервјуи и говори придружени појединим од поменутих дјела. Неке од релација којима ћемо се надаље позабавити јесу: поимање везе књижевности и политике у Ћосићевим дневничким и есејистичким дјелима, богат материјал важан за социологију литературе, као примарне подобласти социологије културе у поменутим дјелима, с посебним акцентом на будућност књиге, односно читаоца и релацију аутор-дјело-читалац, националну културу, национални идентитет и социолошку улогу језика.

Када је у питању веза књижевности и политике, битно је истаћи да је Ћосић писца увијек стављао у први план, али писца који је крајње субверзиван и чији задатак као интелектуалца представља борбу да, како и сам каже у књизи „Стварно и могуће”, „слободна хуманистичка мисао и савест успоставе своју самосталност и интегритет" (Ковијанић 2010: 113). Иако свјестан трагичне судбине интелектуалца (двојако посматране), Ћосић стаје у одбрану писца у политици (који, логично, ван ње не смије ни бити). Он у „Пишчевим записима” каже: „Ако је писцу стало до истине, морала и људског достојанства, он не може имати храбрости за истине о свету и људима на папиру, за писаћим столом, за књигом и у својим књигама; а немати храбрости за живот у људским односима, у јавном животу, у политици, коначно - у стварима судбоносним за свој народ. Ако поступа супротно: ако не каже све што мисли, он би себи био подлац, сматрао би се бедником, кукавицом, човеком недостојним пажње и поштовања" (Ковијанић 2010: 109). Дакле, Ћосић инсистира на оном примарном задатку интелектуалца да врши хуманистичку мисију, која се „потврђује страшћу за истинама по сваку цијену”, како наводи у књизи „Стварно и могуће” (Ковијанић 2010: 113), уз ограду да интелигенција не смије да се потчини тренутку. У том контексту и каже да она „не смије да се жртвује актуелности и никаквим интересима и захтјевима који се сукобљавају са њеним хуманистичким смислом" (Одговорности) (Ковијанић 2010: 114). Према његовом мишљењу, то жртвовање актуелном тренутку значило би аутоматски преношење идеолошке и политичке борбе у књижевност, чиме би се понизила њена улога и уопште смисао (Ковијанић 2010: 110). Он није упао у замку тумачења садашњег тренутка као врхунца прогреса, цивилизације и свијести, беспоштедно се разрачунавајући са свим прошлим сматрајући га анахроним и недостојним. Пишчева окупација су сталне и непролазне вриједности, а прије свих интегритет и трајност истине, односно суочавања са њом. Трајност истине обезбјеђује и трајност пишчевог дјела.

Интегритет, у свој својој пуноћи, означава један од појмова који Ћосић код писца истура у први план. Сама књижевност је за њега трагање за властитим интегритетом, односно „сизифовски посао”. И у својим дневничким записима такав став потврђује говорећи да су и они (ти за- 
писи) напор за постизање властите егзистенције, остварење извјесног, макар фиктивног интегритета, али не и вишак „књижевног” у њему.

Међутим, враћајући се на питање времена и права на жртвовање актуелном тренутку, треба бити опрезан и уочити да Ћосић филозофски маркира и оне теме које извиру из садашњости, а без којих књижевност не вриједи, а које махом реферишу на политичко, дакле, не политикантско. „Само с великим људским садржинама нашег доба и општечовјечанским идејама књижевност може да претраје сва своја невремена; само својом слободом и истинама чије границе одређују дар, разум и савест, књижевност може данас нешто да значи људима" (Ћосић 2009: 94).

Релацију књижевност-политика, неумитно детерминишу и историја и идеологија. Обје „изазивају” књижевност, па писац тако констатује да „нашу (дакле, националну, прим. аут.) књижевност историја изазива да изрази свест о трагичној судбини свога народа и понесе побуну против такве судбине" (Ћосић 2009: 94). Добрица Ћосић се сваким својим дјелом потврдио као свједок, рекли бисмо, низа трагедија које су задесиле српски народ и државу током протеклог вијека. Практично се идентификовао са временом у ком је живио.

Та чињеница, када у анализу узмемо његове дневничке забиљешке, есеје и говоре, да писца увијек истура испред политике, означава уједно и главни разлог, а то је што му је, а он је то схватао, једино писац могао гарантовати какав-такав интегритет о ком је тако често и анатомски прецизно писао.

„Нисам желео да припадам ни једној политичкој странци. Желео сам да останем слободан, независан писац. И кад ме је Вили Брант позвао октобра 1989. у Беч да ми да инструкције за оснивање социалдемократске странке, завршавао сам роман 'Верник' и нисам био спреман да се одрекнем књижевничког заната" (Ћосић 2009: 164). Простије речено, своје идеје, перцепцију релације политика-књижевност потврђивао је непрестано и у пракси. Зар и прве реченице говора приликом избора за предсједника Савезне Републике Југославије 15. јуна 1992. године нијесу биле сличне конотације: „Изузетно тешко стање у коме се нашла наша нова држава приморало вас је да и писца позовете на дужност предсједника Републике. [...] Како не припадам ни једној политичкој странци претпостављам да се ваше поверење и поверење грађана Србије и Црне Горе, које ми налаже најтежу радну и моралну дужност у животу, заснива на мојим књигама и мом јавном раду" (Ћосић 2009: 187). Такође, први дневнички запис књиге „У туђем веку” садржи реченицу: „И сада, на почетку календарског времена које почиње са три нуле, остајем веран занату: писац сам, и то желим да останем док год мислим" (Ћосић 2011б: 6). 
Значајно је примијетити и на који начин Ћосић у поменутој књизи види себе као писца, констатујући да у њему писац постоји „само у сновима", а разлог томе проналази у престанку писања романа, односно „чиљењу нагона романсијера", прецизније, лишавања себе способности измишљања људи и њихових судбина и предавању себе својим записима - фактицитету српске стварности, што је посебно обиљежје првог дијела књиге „У туђем веку”. Та свакодневица, фактицитет, реалност, живот ван литературе, утицали су на то да Ћосић код једног дијела јавности буде виђен као човјек који је „огрезао” у политику. Управо се на овом мјесту и огледа претходно помињани однос. Он се даље пита „да ли ће за коју годину пре мене читавог да умре и писац који још живи у сновима, или ме књижевна подсвест опомиње да треба да напустим реалност и вратим се машти и измишљању света и људских догађања". Више пута спомиње како га старост све више удаљава од романа, а да поетски текст постоји само у његовим сновима, али да је обузет свакодневицом и политиком остао и без снова. Дјелује да је сам себе уморио политиком, да је егзистенцију писца у себи угрозио болном реалношћу. Ипак, 2007. године објављује књигу „Време власти 2”, којом завршава замишљени романсијерски циклус, потврђујући да је писац ипак однио побједу, односно „продужио живот”. Пауза у којој је романсијер Ћосић био заробљен од стране хроничара Ћосића трајала је, као што је познато, готово читаву деценију.

Његови дневнички записи помажу у сагледавању личне перцепције књижевности, њене вриједности, циљева, смисла, трајања.

„Ја сам човек и писац прошлости”, биљежи у књизи „У туђем веку” (Ћосић 2011б: 22). Каже, „Говорим о прошлости - можда ћу освојити неки тренутак будућности. Тај мотив може још увек да одржи мој нагон писања", правдајући овим реченицама, на одређен начин, своју потребу да пише дневник. Изгледа да Ћосић користи дневник како би се са дневником и обрачунао, о чему ће, у наставку, бити више ријечи.

Дана 15. 2. 2001. каже, „Прочитао сам 'Бајку'. Први пут у свом књижевном занату прочитао сам своју књигу. Ту књигу ја нисам написао. Тај Добрица Ћосић који је написао 'Бајку' више не постоји" (Ћосић 2011б: 131). Назива себе и „бившим писцем”, разочаран што редови романа не заузимају мјесто редова дневника. Приређивач његових дјела Ана Ћосић Вукић истиче да писац није сасвим изневјерио романсијера пишући у краткој књижевној форми о својим пријатељима, дакле у књизи „Пријатељи мога века”, јер се „романескни књижевни поступак разоткрива у доживљају да су текстови о његовим пријатељима колико самостални психолошки портрети, толико и повести о међуљудским односима чије су садржаје и судбину одређивала бурна историјска збивања на југословенском простору" (Ћосић 2011а: 423). То такође може послужити и као 
један од аргумената који би могао ићи у прилог тези да се, на извјестан начин, и дневник „У туђем веку” може читати и као роман.

Добрица Ћосић често истиче да „његове књиге више ником нису потребне”, како „неће бити занимљиве савременицима”, већ ће једино бити узете у разматрање код преосталих Срба који се са археолошким побудама буду занимали за српску историју XX вијека. Наглашава да ће његове записе читати можда једино историчари, с обзиром на то да се прије свега бави српском, односно југословенском историјом XX вијека у широком балканском и европском контексту. Његов страх од књижевне смрти надвисио је онај од биолошке. У том контексту, сличне околности почиње да примјећује и ревносно биљежи када је у питању књижевна судбина његових пријатеља, рецимо Оскара Давича, за кога у „Пријатељима мога века” каже: „Српској књижевности оставио је читав метар својих књига, за које знају једино његови образовани савременици; само две-три песничке збирке и роман 'Песму' читају ретки поштоваоци његовог изузетног песничког дара. И његова личност, и идеје које је заступао, и толике књиге које је написао, све је то прошлост која брзо тоне у археолошке остатке једног века који је олујно прохујао" (Ћосић 2011a: 159).

Дакле, Ћосић је константно запитан над судбином сопственог дјела, а та запитаност, одлика великих писаца, црпила је своје коријене и снагу из примјера у окружењу.

Још једна битна ствар када је у питању релација књижевност-политика, јесте сагледавање „штете” коју је политика причинила књижевности, односно писцу Ћосићу, а које је, чини се, више него довољно био свјестан, на шта га је сам дневник све вријеме подсјећао. Анализирајући релацију писац-власт, односно питање да ли су писци на власти више добили или изгубили, Александар Јерков на примјеру Ћосића каже сљедеће:

Јако је то тешко проценити. Неки су невероватно много добили, јер бити уз власт и на власти увек значи бити у пољу привилегија и друштвено повлашћених статуса. Не може се рећи да, на пример, Добрица Ћосић није добио тиме што је као врло млад човек, тридесетогодишњак, своје прве књиге унео у лектиру и што је наредних пола века сваки човек који чита на српском језику морао читати Добрицу Ћосића. То је један добитак и питање је да ли би Ћосић икада стекао књижевни статус (али и наишао на исти отпор) да није био на власти и уз власт. Велико питање је да ли би његово књижевно дело имало исти статус да тога није било. Није реч само о њему, споменуо сам га без негативне предрасуде, као пример за оно што се у великој мери односи и на друге такве ауторе у оба режима. И у монархији и у титоистичкој републици неки су били, да тако кажемо, државно подржани или постављени у хоризонту обавезне лектире (Јерков 2015: 112-113). 
И из наведеног примјера, интересантно је посматрати на који начин се писац може проматрати у одговарајућем друштвено-политичком поретку, односно у контексту историјских прилика.

Анализирајући Крлежину улогу у контексту историјских прилика, у једном запису Добрица Ћосић примјећује да је његова судбина супротна Крлежиној. Каже „ја сам за живота подвргнут толиким порицањима, да би, по некој дијалектици, после моје смрти моје књижевно дело требало да поднесе извесну рехабилитацију, једно озбиљно читање и превредновање”. Такође, сматра он, „ако се историчари књижевности буду бавили мојим делом и идејама које сам заступао, мораће да полемишу са „општим мишљењем” од половине шездесетих година 20. века, са лажима мојих идеолошких непријатеља и службеника иностраних канцеларија" (Ћосић 2015: 16).

\section{1. О дневничкој књижевности}

Претходно споменусмо како Ћосићев унутрашњи сукоб романописца и хроничара, односно свједока једног времена и епохе, дакле сукоб истинског писца и човјека који има потребу да води дневник ради, како сам каже, навике да се дружи са хартијом, игра важну улогу у тумачењу смисла вођења и постојања самог дневника. Упркос томе што Ћосић увиђа да „онај ко пише дневник има много лакши посао да по свескама покупи себе и склопи у књигу” (како истиче у „Пишчевим записима”), истовремено постаје и свјестан драме дневничке књижевности.

Ишчитавајући 'Пишчеве записе', увиђам да је драма дневничке књижевности или пишчевих записа у релативности стварности коју преживљава, и живе свести о пролазности оног што се чини значајним писцу дневника и записа. То што је значајно, за сутра је пролазно, као што је пролазан читав његов живот; али он ту пролазност схвата тек када прочита стари рукопис. Дневничка књижевност изумире истовремено са епистоларном: гаси им се мотивација, јер оне су превсходно емоцијом или сујетом нахрањене. Не вјерујем да би Жид писао дневник на компјутеру. Могао би да га поправља и у том поправљању увек се удаљава од примарног мотива, претварајући рукопис у симулацију или артифицијелност (Ћосић 2011б: 28).

У „Пишчевим записима” упозорава да се и према најпедантније вођеним дневницима треба односити са сумњом, те да је писати мемоаре данас, „заиста доказ лошег укуса” (Ковијанић 2010: 111). 


\section{2. Социлогија литературе}

Када су у питању друштвена производња књижевности и њене друштвене импликације, за пуноћу њиховог сагледавања на националном и свјетском нивоу свакако су незаобилазни Ћосићеви записи, којима он не само што указује на одређене активне чиниоце, већ и визионарски тумачи проблеме везане за социологију литературе или уже за релацију писац-дјело-читалац.

Каткад налик Реју Бредберију и његовим погледима на књигу и читаоца будућности, Ћосић коментарише нашу реалност. Слојеве записа о политици и историјским, судбоносним темама, увезује кратким записима о будућности књижевности, писца, читаоца, уопште културе у ери све агресивније глобализације. За њега ритуалне гужве на сајму књига не представљају ништа друго до доказ да се књиге не купују, већ само гледају. Он се, чињеница је, не да заварати привидом традиције.

Понекад ми се јави жеља да јавно упитам 'нове' писце: на чему то ви које, у најбољем случају, чита неколико стотина људи, верујете да имате неку духовну подлогу, да сте некоме потребни, да вас људи поштују и цене? Живите у привиду традиције да је култура, уметност, књижевност нешто значајно у животу народа. Не увиђате да је велики државни и идеолошки крах на крају века у своје рушевине повукао и читаву националну културу са њеним творцима и верницима. А у реформисаној школи где ће надвладати 'универзални садржај', из читавог 20. века спомињаће се, не и читати, само неколико писаца. Читалац ће бити једна од најређих социјалних појава. Особењак. Биће, просто, зверка. Градска лисица, залутала, гладна, у цичи, зими. Читање ће бити најређе занимање, порок, анахрона страст (Ћосић 2011б: 170-171).

Изречено нас тјера да се запитамо да ли заиста већ живимо у Бредберијевој дистопији описаној у „Фаренхајту 451” (Бредбери 2015).

Даље, наставља да једино филм може спасити потпуног урушавања његову улогу као писца, те да је несрећа његових романа и у томе што су „форматом старински, огромни, гломазни, и самим тим за нови интернетски сензибилитет незанимљива и досадна хартија" (Ћосић 2011б: 171), што је још једна потврда омасовљавања нових, легитимних, књижевних жанрова налик све популарнијој твитератури, на примјер. Оваквим ставовима и замишљеношћу над оним што је услиједило и што ће тек услиједити у ери Вирилиове дромологије, Ћосић се придружио оној групи најелитнијих интелектуалаца која се све чешће и све гласније пита - шта након Гутенбергове ере?

Ћосић у том правцу оправдано страхује за читаоца не само својих дјела већ уопште, црпећи легитимитет за тај страх из факата. Он је 
свјестан да нема моћи да од времена рушилаца одбрани своје књиге, како каже.

Разговарао сам са професорком Јелисаветом Николић [...]. Каже ми да је у јучерашњој анкети (8. 9. 2001) од 90 ученика и ученица, само један ђак, сада четвртог разреда, овог лета прочитао књигу. Тај дечак је, ваљда, случајно читао неке моје романе. Јелисавета каже да никада од кад предаје, а предаје више од три деценије, није примила такву генерацију нечитача. [...] Умире читалачки народ у Србији. Телевизија, немаштина, опште очајништво - убили су књигу (Ћосић 2011б: 177).

Дакле, није то био страх који се код аутора јавио након објављивања прве књиге, како он сам рече „страх од сваке будуће” (Ћосић 2015: 14-15), већ општи страх, судбински, еснафски.

У више наврата у „Пишчевим записима” потцртава да у свијету влада поплава слабе и безвриједне литературе, те да су добре књиге добре по истим критеријумима по којима су добри: аутомобили, пси, парфеми, одјећа, обућа. Добро је оно што се рекламира и прогласи најбољим од стране неког плаћеног суда из масмедија.

\section{3. Језик}

Разматрајући језик, његово стање и културни тренутак у ком егзистира и под чијим се притиском мијења, Ћосић се фокусира на улогу језика као потврде националног и историјског идентитета, изражавајући дубоко жаљење због процеса парцијализације језика на нашем говорном подручју стварајући од њега политичку категорију. Тај процес доживљава као снажну редукцију не само националне историје већ уопште духовног идентитета народа. Стога и изражава негодовање да се о језику и његовој судбини одлучује на форумима које чине људи који су за то посљедњи позвани. О језику, каже Ћосић, прије свих треба да говоре они који га стварају и научно тумаче, они који му у људској заједници свијета дају размјере и значај.

„Језик је наш издајник кога смо свесни” (Ћосић 2011б: 62) и ту наводи фреквентност ријечи које су на неки начин идеолошки обиљежиле одређену политичку и друштвену збиљу - „нема проблема” и „супер”. Појашњава да је синтагма „нема проблема” била карактеристична по фреквентности за социјалистичку епоху у Југославији, а да се након ње појавила ријеч „супер”. Синтагма „нема проблема” указивала је на обиље проблема, махом наслијеђених, док је ријеч „супер” требало да искаже задовољство тренутним стањем. Обје фреквентности говоре о начину на који се језик обичног народа, масе, условно речено су- 
протстављао, али уједно и колаборирао систему у ком је егзистирао изграђујући тако „пожељну" слику друштва. Та промјена фреквентности, примјећује Ћосић, примјетна је и код њега самог, у његовом списатељском раду, али и говору, уз разлику што је, када је он у питању, ријеч „побједа" замијењена ријечју „пораз”.

\section{4. Култура}

Ћосић је у својим дневничким и есејистичким забиљешкама дао дубок поглед на српску и југословенску културу, стања у њој и оцјену извијесних посљедица. Писац је размишљања о култури и културним одређењима ситуирао у три (историјска) периода: социјалистички, затим период од 1989. до 2000. године и након 2000. године. У култури је југословенски пројекат доживио снажан ударац, и то онда када су хрватски писци својом Декларацијом о хрватском књижевном језику затражили напуштање принципа да је српскохрватски један језик. Ћосић, како је сам рекао, „из тактичких разлога” није учествовао у одговору српских писаца, Предлогу за размишљање.

„Ми немамо ниједног писца који би духовном толеранцијом и синтетично мислио о српској култури, не поричући никог ко је нешто створио и значио" (Ћосић 2011б: 51). Писац је то стање третирао као усуд читавог народа, циљајући у извјесној мјери адресе елите и интелигенције које су за то могле и морале понајвише сносити одговорности. И отуда можда и колективни страх од константне (вишедеценијске, па и вишевјековне) провјере, превредновања, ревизија које нијесу плод објективног ангажмана, већ политичких и идеолошких матрица у култури.

„Неће људи да их 'боли глава' за туће 'усијане главе'. И неће људи да ризикују. Али, шта ће онда остати од трајних људских вредности у једном неглавобољном друштву? Шта ће сутра бити култура, духовно и морално наслеђе једног народа чија се стваралачка интелигенција подмићује привилегијама за своју моралну комоцију и духовну лењост, за своје 'здраворазумне' практичне, неглавобољне главе" (Ковијанић 2010: 115), пита Ћосић свјестан управо оне смрти читаоца, и рађања квазиинтелигенције, квазиелите. Детектујући равнодушност и интелектуалну летаргију која узима маха, писац оцртава и конкретизује најтежи, а слободно можемо рећи и главни задатак савремене културе - буђење нове, велике наде.

Иначе, ако нам храброст и знање нису истих размера, наша ће се судбина сасвим изродити у трагикомедију. У том случају, ако ће се протагонисти и саучесници после пада завесе разликовати од неучесника и посматрача, те разлике тешко да ће имати значај који ће потомци сматрати изу- 
зетно часним. Предлажем, дакле: опет у људима будити нову и велику наду. То је, верујем, најтежи задатак савремене културе. Култура је ту улогу у свом изворном мотиву понела и вршила је у свим добима и народима (Ћосић 2010: 130).

Ћосић у својим забиљешкама често страхује, исказује забринутост, уплашен је за колектив, читаоца, идентитет, нацију, језик, елиту, интелектуалца. „Страх је био моје најчешће и најдуже зло, и најдужа патња" (Ћосић 2015: 13), али и најживље памћење, па можда баш свјестан тога, писац храброст и знање ставља у исту раван. На који начин ће, и да ли ће уопште, оваква порука бити примљена остаје да се види. Оно што је сигурно то је да ће сви они који се буду истински интересовали за културу морати предано радити на проналажењу „лијека” и „пута” за ту Ћосићеву наду.

\section{ИЗВОРИ И ЛИТЕРАТУРА}

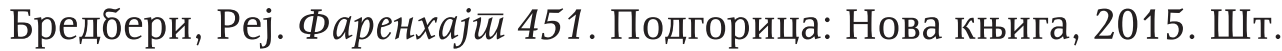

Јерков, Александар. „Мало критиках, малена и мисао, а никаква снага”. Александар Ћуковић. Конйуре хоризонйа (интервјуи). Подгорица: Јумедиа Монт, 2015. Шт.

Ковијанић, Драгутин. Тако је іоворио Добрииа: Добрииа Ћосић - йумач ейохе. Подгорица: Књижевна задруга српског народног вијећа, 2010. Шт.

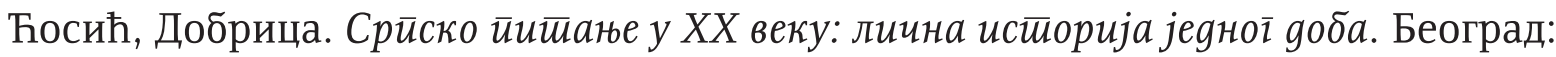
Службени гласник, 2009. Шт.

Ћосић, Добрица. Моћ и сйрейње. Београд: Службени гласник, 2010. Шт.

Ћосић, Добрица. Пријайељи моїа века. Београд: Службени гласник, 2011а. Шт. Ћосић, Добрица. У चиуђем веку. Београд: Службени гласник, 2011б. Шт. Ћосић, Добрица. У йуђем веку II. Београд: Лагуна, 2015. Шт.

Aleksandar D. Ćuković

THE PERCEPTION OF LITERARY AND CULTURAL ASPIRATIONS IN THE DIARY AND ESSAYISTIC WORKS OF DOBRICA ĆOSIĆ

\section{Summary}

This paper deals with the perception of literary and cultural aspirations in the diary and essayistic works of Dobrica Ćosić, primarily in works such as „U tuđem 
veku”, „Moć i strepnje”, "Piščevi zapisi” and "Srpsko pitanje u XX veku”. Also, the paper tries to present Ćosić's understanding of relations such as literature-politics, writer-power, tendencies in culture, language, literature, as well as the understanding of the future of the book and its own literary work. The paper deals with the analysis of culture and literature in the diary notes of Dobrica Ćosić. 